\title{
Effect of food intake on energy and protein metabolism in the skin of Romney sheep
}

\author{
BY P. M. HARRIS*, J. LEE, B. R. SINCLAIR, B. P. TRELOAR AND \\ M. P. GURNSEY \\ AgResearch, Grasslands Research Centre, Private Bag 11008, Palmerston North, New Zealand
}

(Received 13 April 1993 - Revised 22 July 1993 - Accepted 11 August 1993)

\begin{abstract}
Sheep fed on either a low (500 g lucerne (Medicago sativa) chaff/d; L) or high (1100 g lucerne chaff/d; $H$ ) intake had measurements made, using arterio-venous techniques, of blood flow and energy metabolite and cysteine utilization in the skin. Sheep on the $\mathrm{H}$ intake had significantly increased skin blood flow ( $P$ $=0.014)$ and oxygen uptake $(P=0.05)$. Although the $\mathrm{H}$ sheep had higher skin blood flow they showed no difference in skin uptake of either glucose or acetate compared with the $L$ sheep, but the $H$ sheep had a significantly lower output of lactate $(P=0.014)$. Animals in each group had either $\left[{ }^{14} \mathrm{C}\right]$ glucose or $\left[{ }^{14} \mathrm{C} \mid\right.$ acetate infused into the skin which showed that acetate was the predominant precursor of skin sterol and fatty acid synthesis in the $H$ sheep while $L$ sheep skin used both glucose and acetate. The $H$ sheep showed an increase in the net uptake of cysteine by the skin $(P=0.053)$, and in the uptake of cysteine for protein synthesis $(P=\mathbf{0 . 0 7 8})$, relative to the $L$ sheep and this increase was of a comparable magnitude to the increase in blood flow to the skin. Although blood flow, protein synthesis and energy supply increased in the skin of the $H$ sheep by $200-300 \%$, wool production would only have increased by $10-20 \%$, suggesting that nutrient flux changes are not the sole level of regulation of wool production.
\end{abstract}

Skin energy metabolism: Cysteine: Feed intake: Sheep

Regulation of metabolism in the skin of sheep is of productive significance in two ways; first, and directly, because of the significant role of wool production within skin metabolism, second because of the potential for partitioning nutrient supply to the skin, away from other body tissues. Such partitioning could result either in the skin sparing metabolites for use by other tissues or, alternatively, retaining metabolites to the detriment of other tissue function.

Studies of protein metabolism in the skin of sheep (Lobley et al. 1992) and preruminant lambs (Attaix et al. 1988) suggest that in early life skin has a similar protein fractional synthesis rate (FSR; g protein synthesis/d per $\mathrm{g}$ tissue protein) to that of muscle. However, by adult life skin has a higher FSR than that of muscle and makes almost an equal contribution to total body protein synthesis. The results of Lobley et al. (1992) also demonstrated that skin FSR was sensitive to the level of feed intake, but the study was not able to discriminate the processes by which skin regulates these responses to intake. For example, intake-sensitive changes in FSR could be via a modification of blood supply (and thus flux of nutrients to the skin) or through a change in the uptake rate of limiting amino acids by the skin cells. Blood flow to the skin is itself subject to rapid and large changes consequent on the requirements of thermoregulation. These influences can confound measurements of intake responses.

The role of energy metabolites in regulation of skin metabolism is unclear. Harris et al. (1989) in a preliminary arterio venous-difference study of skin metabolism found that

\footnotetext{
* For reprints.
} 
insufficient ATP + GTP energy $(\mathrm{kJ})$ was available for the range of energy-demanding cell functions in the skin. Theoretical calculations of oxygen, glucose and acetate utilization for lipogenesis by the skin (Harris \& Lobley, 1991) suggested that only $175 \mu \mathrm{mol}$ ATP/min per $\mathrm{kg}$ skin were available for the demands of protein turnover, substrate cycling and ion transport, and energy costs exceeded ATP supply, barely providing sufficient ATP to sustain measured levels of protein synthesis. Harris \& Lobley (1991) suggested that the tracer, phenylalanine, used in the measurements on which calculations were based may not have been a good marker for total skin-protein synthesis, perhaps giving an overestimate of synthesis. However, more recent measurements by Lobley et al. (1992), using continuous infusion procedures, demonstrated that phenylalanine actually gave lower estimates of skin FSR than did leucine, in turn making calculations of energy supply in relation to protein synthetic demands based on leucine possibly even more anomalous.

In an attempt to discriminate between the roles of blood flow, amino acid and energy metabolism in limiting skin protein metabolism, measurements were made of blood flow and metabolite flux/uptake by a patch of skin on the midside of sheep given either submaintenance or above-maintenance energy intakes. The measurements were made using a skin arterio-venous difference (A-V) preparation described (Harris et al. 1988), and validated (Dellow et al. 1988), previously.

\section{METHODS}

\section{Animals and surgical preparation}

Ten, 1-year-old Romney ewes $(35-40 \mathrm{~kg})$ had fine-bore polyvinylchloride catheters implanted, under fluothane anaesthesia, in the descending lateral branches of the deep circumflex iliac artery (Al) and vein (V) as described by Harris et al. (1989). A third catheter was implanted in the saphenous artery (A) of each animal. Surgery was undertaken on pairs of sheep at fortnightly intervals. Patency of all catheters was maintained by continuous infusion $(60 \mathrm{ml} / \mathrm{d}$ for arteries; $150 \mathrm{ml} / \mathrm{d}$ for veins $)$ of sterile, heparinized $(30 \mathrm{i} . \mathrm{u} . / \mathrm{ml})$ saline $(9 \mathrm{~g} \mathrm{NaCl} / 1)$. All animals were given prophylactic, broad-spectrum antibiotic coverage (Streptopen; Pitman-Moore, N.Z. Ltd., Upper Hutt, New Zealand) on the day of surgery and for $3 \mathrm{~d}$ following surgery.

Before surgery sheep were maintained indoors in metabolism cages at $18^{\circ}$, on ad lib. lucerne (Medicago sativa) chaff (9.2 MJ metabolizable energy/kg dry matter (DM); $29 \mathrm{~g}$ $\mathrm{N} / \mathrm{kg} \mathrm{DM}$; DM 0.84 as fed) for a minimum adaptation period of 2 weeks. The day before surgery each sheep was offered $500 \mathrm{~g}$ lucerne chaff. Immediately after surgery one sheep from each pair was offered $1100 \mathrm{~g}$ lucerne chaff/d (high intake; $\mathrm{H}$ ), equivalent to $1.4 \times$ energy maintenance $(\mathrm{M})$, while the other was offered $500 \mathrm{~g}$ lucerne chaff/d, equivalent to $0.6 \times \mathrm{M}$ (low intake; L). All feed was delivered in equal hourly portions throughout the day by automatic feeders. At $5 \mathrm{~d}$ after surgery a series of measurements was made on each sheep as described below, and the intake of each sheep was then reversed. Measurements were then made daily on each sheep, as described below. All sheep ate the complete amount of chaff offered between surgery and the first day of measurement. On reversal of intake, concomitant with continuing measurements, some sheep ate less than the total amount of chaff offered. For these, measurements of refusals were made.

At the end of all measurements each sheep was injected with a lethal dose of barbiturate (Sagatal; May \& Baker, Dagenham, Essex). At the same time, coloured latex (3 $\mathrm{ml})$ was infused rapidly into catheter Al. Skin on the flank was then dissected to ensure latex was present throughout the infusion area and that there was no significant appearance of latex in other tissues, e.g. leg muscle. 


\section{Experimental}

Because of the low blood flow and the small size of the blood vessels catheterized in the preparation, considerable difficulty was met in maintaining the patency of catheters, especially the venous catheter, for more than $7-10 \mathrm{~d}$. This being the case, after $5 \mathrm{~d}$ recovery from surgery the main measurements were made in each sheep at one of two levels of intake. Where the preparation remained patent further measurements of the same variables were made on each sheep after a reversal of the original level of intake.

In summary then, as described in detail below, there were four periods of measurement for each animal. (1) During the preliminary period of $5 \mathrm{~d}$ immediately after surgery, feed intakes were set for each animal $(\mathrm{H}$ or $\mathrm{L}$ ) and measurements made of blood flow and oxygen utilization to ensure patency of the preparation. In addition, $3 \mathrm{ml}$ Patent Blue $\mathrm{V}$ was infused rapidly into catheter $\mathrm{Al}$ and the area of skin which flushed rapidly with colour marked to define the infusion zone for biopsy purposes. (2) On Day 1 of measurements (Day 6 after surgery) blood flow and metabolite utilization were determined and then the intakes were reversed. (3) On Day 2 (and daily up to Day 4 depending on the patency of catheter $\mathrm{V}$ ) the measurements made on Day 1 were repeated on each sheep to measure changes in metabolism after intake reversal. (4) On Day 5 all sheep were given a $6 \mathrm{~h}$ infusion of either $\left[{ }^{14} \mathrm{C}\right]$ glucose (two $\mathrm{H}$ and two $\mathrm{L}$ sheep) or $\left[{ }^{14} \mathrm{C}\right]$ acetate (three $\mathrm{H}$ and three $\mathrm{L}$ sheep) to assess incorporation of ${ }^{14} \mathrm{C}$ into fatty acids and waxes in the skin. At the end of this infusion period the sheep were killed as described.

Experimental details. Day 1. A continuous infusion of a solution containing $\left[{ }^{35} \mathrm{~S}\right]$ cysteine $\left(3.7 \times 10^{4} \mathrm{~Bq} / \mathrm{g}\right.$ saline), cysteine $(1 \mu \mathrm{M}), p$-aminohippuric acid $(\mathrm{PAH} ; 200 \mu \mathrm{g} / \mathrm{g}$ saline $)$, and heparin (100 i.u./g saline) in sterile saline was given at $0.36 \mathrm{~g} / \mathrm{min}$ into catheter Al. After a $10 \mathrm{~min}$ period, three consecutive $20 \mathrm{~min}$ incremental blood samples were taken simultaneously from catheters $V$ and $A$ by peristaltic pump at $0.36 \mathrm{~g} / \mathrm{min}$ via PVC tubing and collected (on ice) into tubes containing $0.1 \mathrm{ml} \mathrm{Na}{ }_{2}$ EDTA $(150 \mathrm{~g} / \mathrm{l})$. Part way through each 20 min collection period the collection lines were briefly (about 30 s) removed from the collection tubes and samples of arterial and venous blood collected into $1 \mathrm{ml}$ Eppendorf vials on ice containing $10 \mu \mathrm{l}$ heparinized (1000 i.u./ml) saline and overlaid with paraffin. These samples were used immediately for determination of blood oxygen in each arterio-venous pair.

Immediately on completion of each 20 min sampling period the main blood samples were subsampled for immediate measurement of PAH content and the remainder proteinprecipitated, centrifuged and frozen (as described below).

After completion of the $\left[{ }^{35} \mathrm{~S}\right]$ cysteine infusion, and after a $1 \mathrm{~h}$ interval, a second infusion was given into catheter $\mathrm{Al}$ of a solution containing $\left[\mathrm{U}-{ }^{14} \mathrm{C}\right] \mathrm{glucose}\left(3 \cdot 7 \times 10^{4} \mathrm{~Bq} / \mathrm{ml}\right)$, glucose $(40 \mu \mathrm{g} / \mathrm{g})$, PAH $(200 \mu \mathrm{g} / \mathrm{g})$ and heparin $(100 \mathrm{i} . \mathrm{u} . / \mathrm{g})$ in sterile saline at $0.36 \mathrm{~g} / \mathrm{min}$. After a $10 \mathrm{~min}$ period, three consecutive $20 \mathrm{~min}$ incremental blood samples, including those for blood oxygen determinations were collected from catheters $\mathrm{V}$ and $\mathrm{A}$ and treated as described below.

Days 2-4. Consecutive infusions of $\left[{ }^{35} \mathrm{~S}\right]$ cysteine and $\left[{ }^{14} \mathrm{C}\right]$ glucose were given into catheter $\mathrm{Al}$, samples collected from catheters $\mathrm{V}$ and $\mathrm{A}$, and samples handled as described for Day 1.

Day 5. Either $\left[{ }^{14} \mathrm{C}\right]$ glucose or $\left[{ }^{14} \mathrm{C}\right]$ acetate was infused into catheter $\mathrm{Al}$ for $6 \mathrm{~h}$ $\left(3.7 \times 10^{4} \mathrm{~Bq} / \mathrm{ml}\right.$ in saline at $\left.0.36 \mathrm{~g} / \mathrm{min}\right)$. At the end of this infusion period, but with the infusion still continuing, a $10 \mathrm{~mm}$ diameter skin sample was biopsied from the infusion zone, using a trephine and lignocaine local anaesthesia, and frozen immediately in liquid $\mathrm{N}_{2}$ and stored at $-85^{\circ}$. For the first two sheep a biopsy was taken in the same manner from 
the infusion zone before the start of the ${ }^{14} \mathrm{C}$ infusion and frozen in liquid $\mathrm{N}_{2}$. This sample was used to assess background levels of ${ }^{14} \mathrm{C}$ in the sterol and fatty acids of the skin.

\section{Analysis}

Blood preparation. Oxygen concentration was determined in duplicate on $5 \mu 1$ blood using a galvanic oxygen cell (Grubb \& Mills, 1981), and using $5 \mu 1$ air samples to calibrate the system.

Proteins from blood samples $(1 \mathrm{ml})$ were precipitated with $2 \mathrm{ml}$ trichloroacetic acid (TCA; $100 \mathrm{~g} / \mathrm{l}$ ) and centrifuged at $2000 \mathrm{~g}$. PAH was determined in the supernatant by mixing with an equal quantity by weight of 4-dimethylaminobenzaldehyde $(10 \mathrm{~g} / \mathrm{l})$ in acidified ethanol and measuring the absorbance at $470 \mathrm{~nm}$. Standards were prepared in the same way with known amounts of PAH added to control blood samples.

Sample preparation for the determination of cyst(e)ine concentration and specific radioactivity (SRA) and glutathione concentration was undertaken as described by Lee $e t$ al. (1993) and samples were stored at $-85^{\circ}$ until analysis.

For the determination of glucose and lactate concentrations and corresponding SRA, and acetate concentration, $4 \mathrm{ml}$ samples were mixed with $0.1 \mathrm{ml}$ valeric acid $(50 \mathrm{~mm})$ and then $0.6 \mathrm{M}-\mathrm{HClO}_{4}(1: 2 ; \mathrm{v} / \mathrm{v})$ centrifuged and the supernatant neutralized with a known weight of $3 \mathrm{M}-\mathrm{KOH}$. The neutralized supernatant was stored at $-20^{\circ}$ until analysis.

Cysteine and glutathione determinations. Total ${ }^{35} \mathrm{~S}$ radioactivity was determined in $1 \mathrm{ml}$ of all TCA supernatants mixed with $8 \mathrm{ml}$ of a toluene-triton-based scintillant. Concentrations of total oxidized and reduced cysteine (cyst(e)ine) and total oxidized and reduced glutathione (GSH) in the sulphosalicylic (SSA) or TCA supernatant were measured as their fluorobenzoxadiazole derivatives by HPLC as described by Lee et al. (1993), and recoveries in blood calculated using $\mathrm{N}$-acetylcysteine as an internal standard.

Compounds labelled with ${ }^{35} \mathrm{~S}$ in TCA supernatants were separated on a high-resolution HPLC cation-exchange column as described by Lee et al. (1993) and eluted fractions collected into scintillation vials. Scintillant was added and the relative proportions of ${ }^{35} \mathrm{~S}$ associated with cyst(e)ine, GSH and oxidation products $\left(\mathrm{SO}_{4}{ }^{2-}\right.$, cysteinesulphinic acid, taurine) determined. A sample of the $\left[{ }^{35} \mathrm{~S}\right]$ cysteine infusate was separated in the same way for correction of blood samples for non- ${ }^{35}$ S $]$ cysteine components (Lee et al. 1993).

Glucose and lactate determinations. Concentration of glucose in the blood was determined in the $\mathrm{HClO}_{4}$ supernatant using glucose oxidase $(E C$ 1.1.3.4) and $o$-dianisidine (Sigma Diagnostic Kit 510-A; Sigma Chemicals, USA). Concentrations of L- $(+)$-lactate in the blood was determined in the $\mathrm{HClO}_{4}$ supernatant by measuring the increase in NADH concentration after reaction with L-lactate dehydrogenase $(E C$ 1.1.1.27) in the presence of glutamate-pyruvate transaminase $(E C 2.6 .1 .2)$. Amino acids were removed from subsamples of $\mathrm{HClO}_{4}$ supernatant $(2 \mathrm{ml})$ by passage through Dowex $50 \mathrm{~W}$-X8 ion-exchange resin $(\mathrm{H}+$ form, $50-100$ mesh, $5 \mathrm{ml}$ bed volume). Glucose was separated from lactate by passage through Amberlite IRA-400 (acetate form, $5 \mathrm{ml}$ bed volume) and lactate eluted from the IRA-400 resin with $2 \mathrm{M}$-acetic acid. The separated glucose and lactate eluants were freeze dried, made up to $2 \mathrm{ml}$ in deionized water, and the concentration of glucose and lactate measured in a subsample as described for the $\mathrm{HClO}_{4}$ supernatants. The remainder was used to determine total radioactivity. No significant amount of glucose was found in the lactate samples or of lactate in the glucose samples.

Acetate determination. Concentration of acetate in the blood was determined in the $\mathrm{HClO}_{4}$ supernatant $(0 \cdot 5 \mathrm{ml})$, after acidification with $50 \mu 1 \mathrm{H}_{3} \mathrm{PO}_{4}(500 \mathrm{~g} / \mathrm{l})$, by capillary GLC.

Tissue lipids and waxes. Skin biopsy samples were shattered using a modified French Cell press at liquid $\mathrm{N}_{2}$ temperature. The pellet was extracted with $5 \mathrm{ml} \mathrm{CHCl}_{3}-\mathrm{MeOH}(2: 1 ; \mathrm{v} / \mathrm{v})$ 
and $5 \mathrm{ml} \mathrm{KCl}(10 \mathrm{~g} / \mathrm{l})$ added. The $\mathrm{CHCl}_{3}$ layer was removed to a flask and the pellet reextracted. The $\mathrm{CHCl}_{3}$ layers were combined and rotary evaporated to dryness and the residue redissolved in a small known volume of $\mathrm{CH}_{2} \mathrm{Cl}_{2}$. A known portion of this solution was counted for ${ }^{14} \mathrm{C}$ and the remainder saponified with a solution containing $60 \mathrm{~g} \mathrm{KOH}$ and $940 \mathrm{~g}$ methanol $/ 1$ at $80^{\circ}$ for $120 \mathrm{~min}$. After cooling, the solution was extracted three times with diethyl ether-water $(1: 1 ; \mathrm{v} / \mathrm{v})$ and the ether and aqueous fractions combined separately.

The aqueous fraction, containing the fatty acids, was acidified with $\mathrm{HCl}$, extracted three times with ether, the combined extract dried with $\mathrm{Na}_{2} \mathrm{SO}_{4}$, filtered and taken to dryness by rotary evaporation. The fatty acids were taken up in a known volume of $\mathrm{CH}_{2} \mathrm{Cl}_{2}$ and a known weight counted for ${ }^{14} \mathrm{C}$.

The diethyl ether fraction was taken to dryness, taken up in light petroleum (b.p. $40-60^{\circ}$ ) and passed through a $3 \mathrm{ml}, 0.5 \mathrm{~g}$ silica column (Bond-Elut; Varian SPP, Harbour City, CA, USA) which had been preconditioned with light petroleum. The eluent, containing the hydrocarbon fraction, was taken to dryness, redissolved in $\mathrm{CH}_{2} \mathrm{Cl}_{2}$ and counted for ${ }^{14} \mathrm{C}$. The sterol-alcohol fraction was eluted from the column with three volumes of acetone, evaporated to dryness, taken up in $\mathrm{CH}_{2} \mathrm{Cl}_{2}$ and ${ }^{14} \mathrm{C}$ activity determined.

\section{Calculations}

Blood flow $(\mathrm{ml} \mathrm{blood} / \mathrm{min})$ to the skin area was calculated by dye dilution as:

weight of $\mathrm{PAH}$ infused $/ \mathrm{min}$ into catheter $\mathrm{Al}$

$\overline{\text { [wt } \mathrm{PAH} / \mathrm{ml} \text { blood at catheter } \mathrm{V})-(\text { wt of } \mathrm{PAH} / \mathrm{ml} \text { blood at catheter } \mathrm{A})]}$

Uptake or utilization of oxygen, cyst(e)ine, GSH, acetate or glucose, and output of lactate were calculated as the difference in concentration of each metabolite at $\mathrm{A}$ and $\mathrm{V}$ collection sites multiplied by blood flow.

Fractional uptake of ${ }^{35} \mathrm{~S}\left(\mathrm{Up}{ }^{35} \mathrm{~S}\right)$ or ${ }^{14} \mathrm{C}\left(\mathrm{Up}{ }^{14} \mathrm{C}\right)$ was calculated as:

[(DPM infused $/ \mathrm{ml}$ blood into catheter $\mathrm{Al}+\mathrm{DPM} / \mathrm{ml}$ at catheter $\mathrm{A})$ $-\mathrm{DPM} / \mathrm{ml}$ at catheter $\mathrm{V}] \times$ blood flow

\section{DPM infused $/ \mathrm{min}$}

with ${ }^{35} \mathrm{~S}$ activity being that associated with the cysteine fraction in each case.

Rate of utilization of cysteine for protein synthesis was calculated as:

$(\mathrm{nmol}$ cysteine $/ \mathrm{ml}$ blood at catheter $\mathrm{A}) \times($ blood flow $\mathrm{ml} / \mathrm{min}) \times\left(\mathrm{Up}^{35} \mathrm{~S}\right)$.

Percentage of glucose uptake metabolized to lactate was calculated as:

(lactate $\mathrm{DPM} / \mathrm{ml}$ blood at catheter $\mathrm{V}$-lactate $\mathrm{DPM} / \mathrm{ml}$ blood at catheter $\mathrm{A}) \times 100$

(glucose DPM $/ \mathrm{ml}$ blood infused into catheter $\mathrm{Al}$

+ glucose $\mathrm{DPM} / \mathrm{ml}$ at catheter $\mathrm{A}) \times\left(\mathrm{Up}{ }^{14} \mathrm{C}\right)$

\section{Statistical analysis}

Comparison of the effect of intake was by analysis of variance (Statistical Analysis Systems, 1985). For regression analyses against intake, the data were tested for differences in slopes and intercepts between treatments. In no case were these significant and so a common slope and intercept were applied.

RESULTS

Blood flow to the skin patch of sheep eating $1100 \mathrm{~g}$ lucerne chaff (H intake) was significantly $(P=0.014)$ greater than that to the skin patch of sheep eating $500 \mathrm{~g} / \mathrm{d}(\mathrm{L}$ 
Table 1. Blood flow, arterial concentrations and net uptake by the skin of oxygen, glucose, acetate, cyst(e)ine and glutathione and output of lactate, together with uptake of cyst(e)ine for protein synthesis (by $\left[{ }^{35} S\right] c y s t($ e)ine uptake), measured in a patch of skin in sheep given either $1100(H)$ or $500(L) g$ lucerne (Medicago sativa) chaff/d*

(Values were obtained on Day 1 of measurement and are means with their standard errors for five sheep)

\begin{tabular}{|c|c|c|c|c|c|}
\hline & \multicolumn{2}{|c|}{$\mathbf{H}$} & \multicolumn{2}{|c|}{$\mathrm{L}$} & \multirow{2}{*}{$\begin{array}{c}\text { Probability of } \\
\text { statistical } \\
\text { significance of } \\
\text { intake effects }(P)\end{array}$} \\
\hline & Mean & $\mathrm{SE}$ & Mean & $\mathrm{SE}$ & \\
\hline Blood flow $(\mathrm{g} / \mathrm{min})$ & $26 \cdot 1$ & $6 \cdot 2$ & $7 \cdot 0$ & $2 \cdot 7$ & $0 \cdot 014$ \\
\hline \multicolumn{6}{|l|}{ Glucose } \\
\hline Concentration ( $\mu \mathrm{g} / \mathrm{g}$ blood) & 519 & 25 & 485 & 24 & NS \\
\hline Uptake (g/d) & $1 \cdot 1$ & 0.4 & 0.9 & 0.2 & NS \\
\hline \multicolumn{6}{|l|}{ Lactate } \\
\hline Concentration ( $\mu \mathrm{g} / \mathrm{g}$ blood) & $40 \cdot 3$ & 1.6 & $59 \cdot 5$ & $5 \cdot 6$ & $0 \cdot 014$ \\
\hline Output $(\mathrm{mg} / \mathrm{d})$ & 62 & 45 & 350 & 82 & 0.014 \\
\hline Glucose uptake $\rightarrow$ lactate $(\%)$ & $4 \cdot 0$ & 2.6 & $35 \cdot 1$ & 6.0 & 0.001 \\
\hline \multicolumn{6}{|l|}{ Acetate } \\
\hline Concentration ( $\mu \mathrm{g} / \mathrm{g}$ blood) & $48 \cdot 0$ & $7 \cdot 3$ & $37 \cdot 1$ & $2 \cdot 9$ & NS \\
\hline Uptake $(\mathrm{mg} / \mathrm{d})$ & 255 & 108 & 190 & 51 & NS \\
\hline \multicolumn{6}{|l|}{ Oxygen } \\
\hline Concentration (ml/g blood) & $0 \cdot 151$ & 0.004 & $0 \cdot 144$ & $0 \cdot 014$ & NS \\
\hline Uptake $(\mathrm{ml} / \mathrm{d})$ & 768 & 219 & 259 & 64 & 0.05 \\
\hline \multicolumn{6}{|l|}{ Cysteine } \\
\hline Concentration $(\mu \mathrm{M})$ & $51 \cdot 2$ & $2 \cdot 5$ & $56 \cdot 5$ & $4 \cdot 8$ & NS \\
\hline Net uptake (nmol/min) & $73 \cdot 1$ & $19 \cdot 5$ & $25 \cdot 0$ & $9 \cdot 9$ & 0.05 \\
\hline Uptake by ${ }^{35} \mathrm{~S}(\mathrm{nmol} / \mathrm{min})$ & 476 & 157 & 175 & 254 & NS \\
\hline \multicolumn{6}{|l|}{ Glutathione } \\
\hline Concentration $(\mu \mathrm{M})$ & 1475 & 70 & 1532 & 141 & NS \\
\hline Net uptake (nmol/min) & 82 & 542 & 1037 & 321 & NS \\
\hline
\end{tabular}

NS, not significant. $(P>0.05)$.

* For details of treatments and procedures, see pp. 648-651.

intake) by about three to fourfold, on Day 1 of measurement, $5 \mathrm{~d}$ after surgery (Table 1 ). Level of intake had no significant effect on arterial concentration of oxygen, glucose or acetate (Table 1) although in each case the $L$ sheep had a trend for lower arterial concentration of these metabolites than the $\mathrm{H}$ sheep. In combination with significantly enhanced blood flow, fluxes of oxygen, glucose and acetate to the skin of the $\mathrm{H}$ sheep were also greater than that of the $\mathbf{L}$ sheep. However, arterial lactate concentration was significantly lower in the $\mathrm{H}$ sheep than that in the $\mathrm{L}$ sheep. Uptake of oxygen by the skin of $\mathrm{H}$ sheep was significantly $(P=0.05)$ enhanced relative to the $\mathrm{L}$ sheep (Table 1$)$. This was in proportion with the increase in blood flow (about threefold). In contrast, although there was a trend for an increase in uptake of both glucose and acetate by the skin of the $\mathrm{H}$ sheep this was not significant and small relative to the increase in blood flow. Net output of lactate by the skin of the $\mathrm{H}$ sheep was significantly lower $(P=0.014)$, only $20 \%$ of that in the $\mathrm{L}$ sheep, and this was achieved by a significantly $(P<0.001)$ reduced proportion of the glucose uptake being transformed to lactate in the skin of the $\mathrm{H}$ sheep $(4.0 \%$ and $35.1 \%$ for the $\mathrm{H}$ and $\mathrm{L}$ sheep respectively).

The arterial concentration of both cyst(e)ine and GSH did not change significantly with intake (Table 1) but there was a significant $(P=0.05)$ enhancement in the rate of net uptake of cyst(e)ine by the skin of $H$ sheep compared with the $L$ sheep skin $(73.1$ and $25.0 \mathrm{nmol} / \mathrm{min}$ respectively). The greater uptake of cyst(e)ine in the skin patch of $\mathrm{H}$ sheep 
Table 2. Relationships between metabolic variables measured over $2-4 d$ in the skin patch $(Y)$ and food intake $(X ; g$ lucerne (Medicago sativa) chaff/d) by combining data from two groups of sheep after a change from being offered 1100 to $500 \mathrm{~g} / \mathrm{d}$ and 500 to $1100 \mathrm{~g} / \mathrm{d}^{*}$

(Mean values and standard deviations for ten sheep)

\begin{tabular}{|c|c|c|c|c|}
\hline Variable $(Y)$ & Regression equation & $\begin{array}{l}\text { Residual } \\
\mathrm{df}\end{array}$ & $\begin{array}{l}\text { Probability of } \\
\text { significant linear } \\
\text { relationship of } \\
\text { metabolite with } \\
\text { intake }(P)\end{array}$ & $\begin{array}{l}\text { Variance } \\
\text { accounted for } \\
\text { by the } \\
\text { regression } \\
(r)\end{array}$ \\
\hline Blood flow $(\mathrm{g} / \mathrm{min})$ & $Y=1.8( \pm 6.2)+0.027( \pm 0.008) X$ & 26 & 0.003 & 0.55 \\
\hline \multicolumn{5}{|l|}{ Glucose } \\
\hline Concentration & - & - & NS & - \\
\hline Uptake & - & - & NS & - \\
\hline \multicolumn{5}{|l|}{ Lactate } \\
\hline Concentration & - & - & NS & - \\
\hline Output (mg/d) & $Y=438( \pm 88)-3 \cdot 5( \pm 1 \cdot 3) X$ & 26 & $0 \cdot 011$ & 0.51 \\
\hline $\begin{array}{l}\text { Glucose uptake } \rightarrow \text { lactate } \\
(\%)\end{array}$ & $Y=62( \pm 13)-0.046( \pm 0.018) X$ & 26 & $0 \cdot 019$ & $0 \cdot 40$ \\
\hline \multicolumn{5}{|l|}{ Acetate } \\
\hline Concentration $(\mu \mathrm{g} / \mathrm{g})$ & $Y=18.0( \pm 5.3)+0.033( \pm 0.007) X$ & 26 & 0.001 & 0.69 \\
\hline Uptake $(\mathrm{mg} / \mathrm{d})$ & - & - & NS & - \\
\hline \multicolumn{5}{|l|}{ Oxygen } \\
\hline $\begin{array}{c}\text { Concentration } \\
(\mathrm{ml} / \mathrm{g} \text { blood })\end{array}$ & $Y=12.6( \pm 1 \cdot 2)+0.0027( \pm 0.0016) X$ & 26 & NS & - \\
\hline Uptake $(\mathrm{ml} / \mathrm{d})$ & $Y=194( \pm 176)+0.543( \pm 0.23) X$ & 26 & 0.02 & $0 \cdot 40$ \\
\hline \multicolumn{5}{|l|}{ Cysteine } \\
\hline Concentration & - & - & NS & - \\
\hline Net uptake (nmol/min) & $Y=-22( \pm 96)+0.22( \pm 0.12) X$ & 26 & NS & $0 \cdot 30$ \\
\hline Uptake by ${ }^{35} \mathrm{~S}$ & - & - & NS & - \\
\hline
\end{tabular}

NS, not significant. $(P>0 \cdot 05)$.

* For details of treatments and procedures, see pp. 648-651.

was of a similar magnitude (about threefold) to the increase in skin blood flow (Table 1). In the skin of the $\mathrm{H}$ sheep the uptake of cyst(e)ine for protein synthesis was also much greater as measured by uptake of $\left[{ }^{35} \mathrm{~S}\right] \mathrm{cyst}(\mathrm{e})$ ine although there was considerable variation (Table 1), and again the increase in rate was of a similar size to the increase in blood flow. Measurements of GSH uptake had a very high level of variation, the large circulating pool means that a small error in the proportion of glutathione in either the $\mathrm{A}$ or $\mathrm{V}$ sample gives a large absolute change in apparent uptake. Nevertheless, there is a trend that while cyst(e)ine uptake is enhanced during high intake, GSH uptake is reduced $(P=0 \cdot 16$; Table 1). Net uptakes of oxygen, glucose, acetate or cysteine were not significantly related to their circulating concentration.

After the first day of measurements the feed allowance offered to each group of sheep was reversed (1100 to $500 \mathrm{~g}$ and 500 to $1100 \mathrm{~g})$ and measurements repeated for the next few days. Not all sheep ate the allowance offered over this period; however, measurements from both groups of sheep were combined and regressed against the individual feed intake over the $24 \mathrm{~h}$ before measurement, and the same major responses to intake were found as in the direct measurements made on Day 1 (Table 2) with responses occurring within $24 \mathrm{~h}$. In addition, arterial acetate concentration showed a strong relationship with intake $(P<$ $0.001)$. Blood flow to the skin significantly increased $(P=0.003)$ with increasing intake, as did uptake of oxygen $(P=0 \cdot 02)$. There was no significant relationship between uptake of glucose or acetate and intake but lactate output significantly declined with increasing intake 
Table 3. Cumulated ${ }^{14} \mathrm{C}$ activity in the sterol and fatty acid fractions of lipid in the skin of sheep, infused with either $\left[{ }^{14} \mathrm{C}\right]$ glucose or $\left[{ }^{14} \mathrm{C}\right]$ acetate directly into the skin for $6 \mathrm{~h}$, and offered either $1100(H)$ or $500(L) g$ lucerne (Medicago sativa) chaff/d*

(Mean values and their standard deviations)

\begin{tabular}{|c|c|c|c|c|c|c|c|c|}
\hline \multirow{3}{*}{$\begin{array}{l}\text { Precursor source of }{ }^{14} \mathrm{C} \ldots \\
\text { Number of sheep ... }\end{array}$} & \multicolumn{4}{|c|}{$\mathrm{H}$} & \multicolumn{4}{|c|}{$\mathrm{L}$} \\
\hline & \multicolumn{2}{|c|}{$\begin{array}{c}\text { Glucose } \\
2\end{array}$} & \multicolumn{2}{|c|}{$\begin{array}{l}\text { Acetate } \\
3\end{array}$} & \multicolumn{2}{|c|}{$\begin{array}{l}\text { Glucose } \\
2\end{array}$} & \multicolumn{2}{|c|}{$\begin{array}{c}\text { Acetate } \\
3\end{array}$} \\
\hline & Mean & SD & Mean & SD & Mean & SD & Mean & SD \\
\hline Lipid extracted (mg/g skin) & 50 & 9 & 26 & 15 & 53 & 9 & 41 & 8 \\
\hline Total DPM/mg total lipid & 24 & 8 & 4056 & 611 & 556 & 341 & 601 & 103 \\
\hline Total DPM/g skin $\left(\times 10^{3}\right)$ & $1 \cdot 2$ & $0 \cdot 1$ & 102 & 119 & $27 \cdot 8$ & $14 \cdot 1$ & $22 \cdot 1$ & $32 \cdot 0$ \\
\hline Total DPM in sterols (\%) & 45 & 21 & 24 & 1 & 38 & 7 & 31 & 1 \\
\hline Total DPM in fatty acids $(\%)$ & 49 & 12 & 55 & 7 & 39 & 6 & 57 & 10 \\
\hline
\end{tabular}

DPM, disintegrations per minute.

* For details of treatments and procedures, see pp. 648-651.

$(P=0.011)$. Similarly the proportion of glucose uptake anaerobically oxidized to lactate was also reduced. There was an increase in the net uptake of cyst(e)ine by the skin patch as intake increased $(P=0.08)$.

At $5 \mathrm{~d}$ after reversal of intake, sheep were infused through catheter $\mathrm{Al}$ with either $\left[{ }^{14} \mathrm{C}\right]$ glucose or $\left[{ }^{14} \mathrm{C}\right]$ acetate directly into the skin patch. Samples taken from two sheep before the start of infusion showed that the ${ }^{14} \mathrm{C}$ activity associated with the total lipid fraction, and with the sterols and waxes, was less than $5 \%$ of the activity at the end of the infusion period. For those sheep on the $\mathrm{L}$ intake the ${ }^{14} \mathrm{C}$ activity associated with the skin lipid fraction was comparable for acetate and glucose as the precursor source (Table 3 ). However, on the $\mathrm{H}$ intake very little ${ }^{14} \mathrm{C}$ was associated with lipid derived from $\left[{ }^{14} \mathrm{C}\right]$ glucose while very large amounts of $\left[{ }^{14} \mathrm{C}\right]$ acetate labelled the skin lipid fraction in $\mathrm{H}$ sheep relative to either the $\left[{ }^{14} \mathrm{C}\right]$ glucose on $\mathrm{H}$ intake, or both $\left[{ }^{14} \mathrm{C}\right]$ glucose and $\left[{ }^{14} \mathrm{C}\right]$ acetate on $\mathrm{L}$ intake. These very big differences between acetate and glucose as precursors in the total lipid pool did not however change the proportional distribution of the ${ }^{14} \mathrm{C}$ label from each precursor into either sterols or fatty acids; on both $\mathrm{L}$ and $\mathrm{H}$ intakes $\left[{ }^{14} \mathrm{C}\right] \mathrm{glucose}$ distributed about equally between sterols and fatty acids while only about half the activity from acetate appeared in the sterol fraction as appeared in the fatty acid fraction (Table 3 ).

The weight of skin infused in each group, as measured on slaughter after latex infusion and dissection, did not differ between groups, with the five sheep finishing on the L intake having 87 (SE 17) g infused skin (area $247\left(\mathrm{SE} \mathrm{31)} \mathrm{cm}^{2}\right.$ ) and the five sheep finishing on the $\mathrm{H}$ intake having 94 (SE 19) $\mathrm{g}$ of infused skin (area $281\left(\mathrm{SE} \mathrm{38)} \mathrm{cm}^{2}\right.$ ).

\section{DISCUSSION}

The skin arterio-venous preparations

As discussed elsewhere (Harris \& Lobley, 1991; Harris et al. 1992) there are several shortcomings in the $\mathrm{A}-\mathrm{V}$ procedure for the assessment of metabolic responses in tissues. Most of these problems are general to all $\mathrm{A}-\mathrm{V}$ preparations, the most important being the problem of assessing the SRA of the true amino acid precursor of protein synthesis because of differences in SRA between various available pools (vascular, extracellular, intracellular). In the case of the A-V measurements the vascular SRA will exceed the intracellular SRA 
and, hence, in many tissues an underestimate of protein synthesis could be obtained. In the case of skin, however, Lobley et al. (1992) have shown that estimates based on the vascular SRA, rather than the intracellular SRA, best represent the precursor pool when compared with the 'flood' procedure.

A second problem is that many $\mathrm{A}-\mathrm{V}$ preparations are of mixed tissue types, in the case of the hindlimb preparation a mixture of skin, muscle, fat and bone, while the skin preparation is predominantly skin but can contain up to $25 \%$ subcutaneous muscle (Harris et al. 1989). Short-term intake changes are unlikely to affect the proportions of the tissues present; nevertheless the skin and muscle could respond differentially, with respect to their metabolism, to different intake levels. However, Lobley et al. (1992) showed that although skin had a higher FSR (g protein synthesized/g protein per d) than muscle, skin and muscle responded to intake in a similar manner.

Collateral circulation is a potential problem with many $\mathrm{A}-\mathrm{V}$ preparations. The skin preparation has been shown to give overestimates of flow by about $10 \%$ at normal blood flows (Dellow et al. 1988) but this may vary with blood flow rate. Possible problems with collateral circulation are of special significance with the skin preparation because the catheterized vessels are very small $(<1 \mathrm{~mm}$ diameter) which makes the use of implantable flow probe cuffs inappropriate. Blood flow measurements must therefore be made by dye dilution. The small size of the vessels, and the associated low blood flows, means that maintenance of catheter patency (especially the venous catheter) is more difficult and measurements can only be made on each animal for a limited time. In addition, the region of the deep circumflex iliac vessels where the catheter tips are positioned is highly branched and small shifts in catheter position can modify the size of the patch infused or sampled (or both). This problem can be controlled by the use of Patent Blue V to validate catheter positioning before each measurement period, and the latex infusion and dissection on slaughter.

Despite these reservations the skin $\mathrm{A}-\mathrm{V}$ preparation is still the only procedure by which repeated measurements of skin metabolism, both protein and energy, can be made in vivo in the same animal under changing physiological conditions. The problems with the preparation may mean that absolute measurements are not possible, but relative changes in metabolism are able to be studied in detail.

\section{Intake and skin energy metabolism}

The major skin response to changing intake from sub-maintenance $(0.6 \mathrm{M} ; \mathrm{L})$ to above maintenance $(1.4 \mathrm{M} ; \mathrm{H})$ energy was a greater than threefold increase in blood flow after $5 \mathrm{~d}$ at each intake level. This response can be compared with that in the hindlimb where increases of only $50 \%$ blood flow were shown over a greater intake range (300-900 g grass pellets/d; $0.6 \mathrm{M}-1.8 \mathrm{M}$; Harris et al. 1992). In other work changes in available energy intake, without changes in protein intake, gave either no response in hindlimb blood supply (Bird et al. 1981) or an increase of about $50 \%$ hindlimb blood flow with the change from sub-maintenance to maintenance energy intake (Oddy et al. 1984; 1985). In the present study the increase in skin blood flow in response to intake change was rapid; even combining data from sheep changed from $\mathrm{L}$ to $\mathrm{H}$ with data from sheep changed from $\mathrm{H}$ to $\mathrm{L}$, a very significant relationship was found suggesting a sensitive adaptive process. In this respect the skin behaves much like the lactating mammary gland where blood flow responded to intake change within $10 \mathrm{~h}$ with a doubling of flow, in turn affecting energy and protein metabolism and milk output (Davis \& Collier, 1985).

It has been generally accepted that skin has a low oxygen demand because of a predominantly anaerobic metabolism based around the pentose phosphate pathway. This tenet was based on 'in vitro' preparations of follicles and skin (Leng \& Stephenson, 1965; 
Chapman \& Ward, 1979) showing significant amounts of acetate utilization and lactate production. Our own preliminary measurements (Harris et al. 1989) also showed a low uptake of oxygen and a high output of lactate by skin relative to tissues such as muscle. In the current study the same effects are seen in the skin of the $\mathrm{L}$ intake animals. There was a relatively low uptake of oxygen (about $89 \mu \mathrm{mol} / \mathrm{min}$ per $\mathrm{kg}$ tissue assuming a skin patch weight of $90 \mathrm{~g}$ ) compared with resting and active muscle on a maintenance intake (120-730 $\mu \mathrm{mol} / \mathrm{min}$ per $\mathrm{kg}$ tissues; Bird et al. 1981), but a high uptake of glucose ( $40 \mu \mathrm{mol} / \mathrm{min}$ per $\mathrm{kg}$ tissue) relative to resting muscle $(7 \mu \mathrm{mol} / \mathrm{min}$ per $\mathrm{kg}$ tissue; Bird et al. 1981) and a high output of lactate $(30 \mu \mathrm{mol} / \mathrm{min}$ per $\mathrm{kg})$ relative to muscle. Resting muscle actually takes up lactate $(2 \mu \mathrm{mol} / \mathrm{min}$ per $\mathrm{kg}$; Bird et al. 1981) and even with exercise exports only $0.3 \mu \mathrm{mol} / \mathrm{min}$ per $\mathrm{kg}$ (Bird et al. 1981). However, in the $\mathrm{H}$ sheep there is a complete change in skin metabolism, with a high oxygen utilization $(264 \mu \mathrm{mol} / \mathrm{min}$ per $\mathrm{kg}$ ) associated with a much lower lactate output of $5 \mu \mathrm{mol} / \mathrm{min}$ per $\mathrm{kg}$, suggesting that the skin has moved from predominantly anaerobic to aerobic oxidation of glucose.

If all of the oxygen uptake by the skin patch at each intake is assumed to be used in glucose oxidation then $5.72 \mathrm{mmol}$ glucose/d is aerobically oxidized on the $\mathrm{H}$ intake compared with $1.93 \mathrm{mmol} / \mathrm{d}$ on the $\mathrm{L}$ intake, leaving 0.38 and $3.27 \mathrm{mmol}$ glucose/d for anaerobic oxidation in the $\mathrm{H}$ and $\mathrm{L}$ skin patches respectively. This compares with measured lactate outputs of 0.6 and $3.9 \mathrm{mmol} / \mathrm{d}$ ( 2 mol lactate produced for each mol of glucose). Overall, the skin at the $\mathrm{H}$ intake is comparable to muscle in its glucose metabolism. This suggests that in both the in vitro data (Chapman \& Ward, 1979) and in our preliminary measurements (Harris et al. 1989) experiments were undertaken in preparations in the equivalent of overall negative energy and protein balance. The skin, because it is more able to utilize substrates by anaerobic means during periods of low intake, allows metabolism to be dissociated from demands of oxygen supply, e.g. in response to the demands of thermoregulation as well as intake. But, given more optimal conditions for the whole animal, the skin responds dynamically to achieve a more aerobic metabolism.

To integrate further the results of the present study the metabolism of acetate and the synthesis of lipids (both fatty acids and sterols for wool wax secretion) must also be accounted for. The measured uptake and output data for oxygen, glucose, acetate and lactate given in Table 1 and the measured relative molar movements of ${ }^{14} \mathrm{C}$ from glucose and acetate into sterols and waxes (Table 3) were fitted into the hypothetical scheme proposed by Harris \& Lobley (1991) for both the $\mathrm{L}$ and the $\mathrm{H}$ intakes (Table 4). The simultaneous equations were solved to give amounts of glucose and acetate used to form lanosterol or palmitate respectively and, hence, the ATP production of the skin at each intake. These calculations only account for the production of skin lipid and assume it to be dominated by the production of wool wax. They do not attempt to account for the slow turnover of storage lipid (gain or loss) in the skin tissue, nor for other possible minor precursors of lipid synthesis such as other circulating volatile fatty acids or ketones.

In order to balance the overall equation while retaining the measured values, very different metabolism is required for each intake. At $\mathrm{L}$ intake levels, both glucose and acetate contribute to lipid synthesis and, because of low oxygen availability, nearly $40 \%$ of glucose is anaerobically oxidized to lactate. There is also considerable activity of the pentose-phosphate pathway needed to generate the required NADPH. In contrast, in sheep switched to the $\mathrm{H}$ intake the calculated predominant source of lipid is acetate with only a very small contribution from glucose, and this is confirmed directly by the $\left[{ }^{14} \mathrm{C}\right]$ acetate and $\left[{ }^{14} \mathrm{C}\right]$ glucose infusions (Table 4 ). The pentose-phosphate pathway is functioning only at about the same level as at $\mathrm{L}$ intake while $85 \%$ of glucose is oxidized aerobically for ATP production.

Calculated production of total lipid by these two metabolic systems is about equal, which 
Table 4. Metabolism of glucose and acetate in the sheep skin as lipogenic precursors of wool wax of sheep fed on either $1100(H)$ or $500(L) g$ lucerne (Medicago sativa) chaff/d*

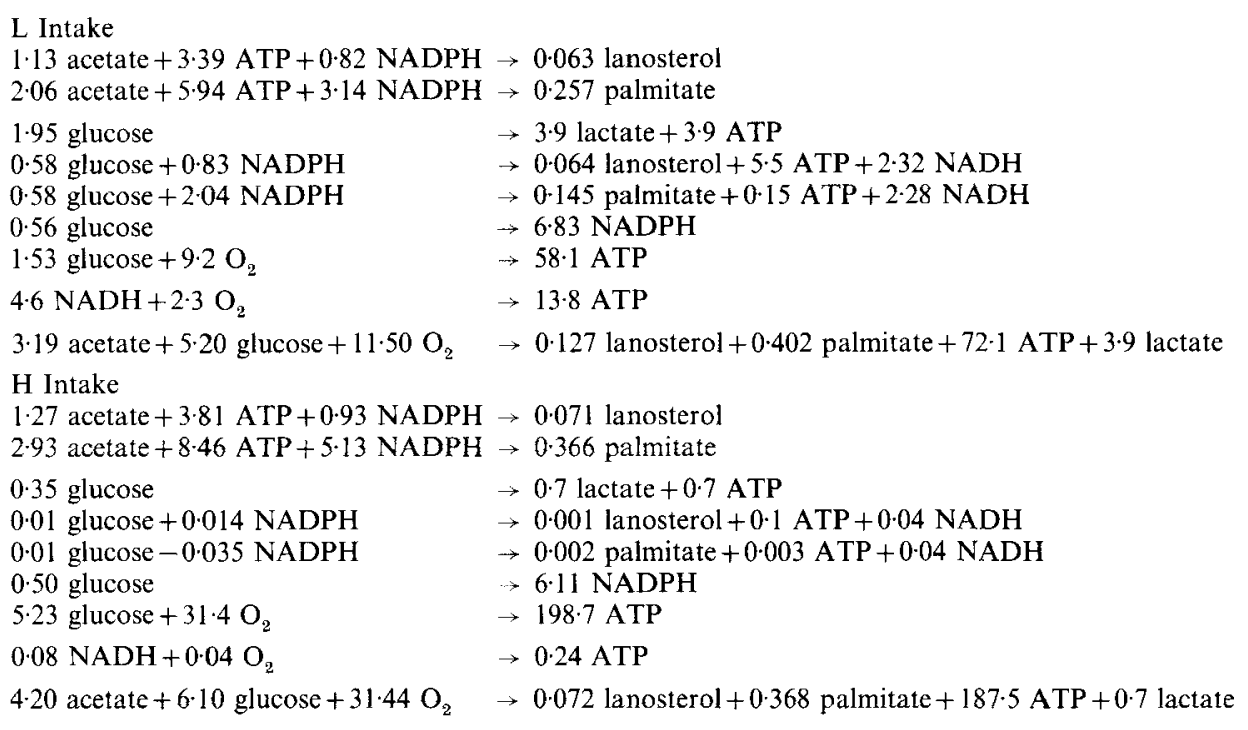

* Overall scheme based on that proposed by Harris \& Lobley (1991), with calculations based on total glucose, acetate, lactate and oxygen uptake and output values from Table 1, and the molar ratios of glucose or acetate moving into fatty acids from Table 3 . Values are given as $\mathrm{mmol} / \mathrm{day}$ in patch of skin for which the mean arterio-venous difference measurements are given (Tables 1 and 3 ).

is not unreasonable, as in a separate trial of sheep given 1100 or $500 \mathrm{~g}$ lucerne chaff/d wool production was shown to be similar with $2.0 \mathrm{mg} / \mathrm{d}$ per $\mathrm{cm}^{2}$ for the $1100 \mathrm{~g} / \mathrm{d}$ group and $1.7 \mathrm{mg} / \mathrm{d}$ per $\mathrm{cm}^{2}$ in the $500 \mathrm{~g} / \mathrm{d}$ group (Harris et al. 1994) and wool wax production is proportional to wool production (Thornberry \& Atkins, 1984).

\section{Intake and skin protein synthesis}

The skin patch ATP production calculated for each intake level (Table 4) increases by twoto threefold as do oxygen uptake and blood flow. Transport of glucose and acetate into the skin cells appears to be unaffected by nutrient flux but the oxygen uptake is constrained and thus regulates available energy. The probable energy costs of the skin have been discussed in detail (Harris \& Lobley, 1991). Compared with most other peripheral tissues it appears that the predominant cost is that of protein synthesis at up to $70 \%$ of energy demand, with only minor demands from ion transport (about $10.6 \%$ of energy expenditure; R. J. Early and B. W. McBride, personal communication), substrate cycles and specialist demands such as thermoregulation. In the current study estimates of protein synthesis were based on net uptake of cyst(e)ine and uptake of $\left[{ }^{35} \mathrm{~S}\right] \mathrm{cyst}(\mathrm{e})$ ine into the skin patch.

The measurement of net uptake of cyst(e)ine reflects gain of protein by the skin patch over the period of measurement. In 1-year-old sheep, over the $1 \mathrm{~h}$ period of measurement, there will be little gain in skin protein. Therefore, the net protein gain can be assumed to be largely that of wool protein which has a typical composition of $9 \cdot 1 \mathrm{~g}$ cyst(e)ine $/ 16 \mathrm{~g} \mathrm{~N}$ (Harris \& Lobley, 1991). The measured net uptake of cyst(e)ine then gives a calculated wool protein production of 0.14 and $0.05 \mathrm{~g} / \mathrm{d}$ in the skin patch of the $\mathrm{H}$ and $\mathrm{L}$ sheep respectively. 
A parallel trial of wool production gave wool productions of 2.0 and $1.7 \mathrm{mg} / \mathrm{cm}^{2}$ per $\mathrm{d}$ for the $\mathrm{H}$ and $\mathrm{L}$ sheep or about $0.50 \mathrm{~g} / \mathrm{d}$ and $0.45 \mathrm{~g} / \mathrm{d}$ in the equivalent patch areas (Harris et al. 1994). Thus net uptake of cyst(e)ine measured cannot account for all the output of cyst(e)ine as wool. This may be a consequence of the relatively recent surgical modification of the skin patch causing wool production to be lower than in unmodified sheep, but, more likely, other sources of cyst(e)ine must also be considered, such as GSH and methionine.

The large variation in measurements of GSH uptake from A-V differences prevented demonstration of uptake for the $\mathrm{H}$ intake group. However, there is some evidence for uptake of GSH by the skin of $\mathrm{L}$ intake sheep which requires further investigation as a precursor of wool cyst(e)ine. Close infusion of $\left[{ }^{35} \mathrm{~S}\right] \mathrm{glutathione}$ into the skin of sheep has shown its uptake to be significantly related to wool production (Harris et al. 1993). The current study did not measure methionine uptake but we have recently shown the appearance of $\left[{ }^{35} \mathrm{~S}\right] \mathrm{cyst}(\mathrm{e})$ ine in the skin free amino acid pool after close infusion with $\left[{ }^{35}\right.$ S]methionine (J. Lee, unpublished results), and work to assess the contribution of methionine to cysteine metabolism in the skin via transulphuration is continuing.

The net uptake of cyst(e)ine and the uptake of $\left[{ }^{35} \mathrm{~S}\right]$ cyst(e)ine both increased two- to threefold with intake change from $\mathrm{L}$ to $\mathrm{H}$, again an increase of comparable size to the increase in nutrient flux and blood flow. This increase is similar to that shown by Lobley et al. (1992), using a flood dose of phenylalanine, who measured a change in skin protein FSR from 0.0565 to 0.0948 with an intake of either $300 \mathrm{~g} / \mathrm{d}(0.6 \mathrm{M})$ or $900 \mathrm{~g} / \mathrm{d}(1.8 \mathrm{M})$ grass pellets in $35 \mathrm{~kg}$ lambs. Calculations of skin protein FSR based on the $\left[{ }^{35} \mathrm{~S}\right] \mathrm{cyst}(\mathrm{e})$ ine uptake by the skin patch in the present study (assuming $2.7 \mathrm{~g}$ cyst(e)ine/16 g N ; Harris \& Lobley, 1991) gives values of total protein synthesis of 3.07 and $1.13 \mathrm{~g} / \mathrm{d}$, or FSR values of about 0.153 and 0.056 , for the $H$ and $L$ intakes respectively. Such values are slightly higher than the flood phenylalanine estimates of Lobley et al. (1992). As already discussed, the A-V procedure used in the present trial may give an underestimate of absolute protein synthesis, but counteracting that underestimate is an overestimate resulting from the very large difference of cyst(e)ine in skin and wool protein $(2.7$ and $9.1 \mathrm{~g} / 16 \mathrm{~g} \mathrm{~N}$ respectively; Harris $\&$ Lobley, 1991). The calculated FSR will depend on the relative rates of protein synthesis in each protein type: a higher proportion of wool protein synthesis will lower the FSR. Whatever the relative ratios of wool protein synthesis and skin protein synthesis are, the proportion appears to be similar at both intake levels with estimates of 15.4 and $14.3 \%$ wool protein synthesis (based on net cyst(e)ine uptake) of total protein synthesis for the $\mathrm{H}$ and $\mathrm{L}$ sheep respectively. It should be noted, however, that if the estimated wool production values already discussed $(0.5 \mathrm{~g} / \mathrm{d}$ and $0.45 \mathrm{~g} / \mathrm{d}$ for the patches of the $\mathrm{H}$ and $\mathrm{L}$ sheep respectively) are compared with total skin synthesis, the proportions are $16 \%$ for the $\mathrm{H}$ sheep and $40 \%$ for the $\mathrm{L}$ sheep. It does seem likely that wool protein synthesis could be a greater proportion of total skin synthesis at below maintenance intakes, and again this suggests that other sources of cysteine such as GSH and methionine must be contributing to wool production.

Using the estimated values of skin protein FSR and assuming that 4 mol ATP are required for each $1 \mathrm{~mol}$ of peptide bond formation, then the ATP requirements of the skin patch for protein synthesis are $108 \mathrm{mmol} / \mathrm{d}$ and $39 \mathrm{mmol} / \mathrm{d}$ for the $\mathrm{H}$ and $\mathrm{L}$ intakes respectively. These demands for ATP are in turn 58 and $54 \%$ of the available ATP calculated in Table 4. Although lower than previous estimates of the proportion of total skin ATP used for protein synthesis (Harris et al. 1989) these estimates are still very high compared with other tissues, e.g. whole body (MacRae \& Lobley, 1986) and muscle (Lobley, 1990) at about 20\%, confirming protein synthesis in the skin as the major energy cost at both low and high intake levels. 


\section{CONCLUSIONS}

The major measured response of the skin of sheep to an increase in food intake was an increase in skin blood flow. Although the uptake of some metabolites (glucose and acetate) appear to be independent of blood flow, both oxygen and cysteine uptake by the skin increase to the same extent as blood flow in response to intake changes. At the same time there is no relationship between oxygen or cysteine uptake and their arterial concentration. This is in contrast to muscle metabolism, where a relationship between uptake of an amino acid and its arterial concentration has been demonstrated, as well as a relationship with blood flow itself (Oddy \& Lindsay, 1986; Harris et al. 1992). Protein synthetic and energy supply demands of the skin are therefore both dependent on changes in blood supply (or metabolite flux) to respond to changes in food intake and hence skin behaves more like the lactating mammary gland (Davis \& Collier, 1985).

These relationships for total skin metabolism, however, cannot be extrapolated to wool production for two reasons: first, wool production by sheep at the two different intake levels changed by only $10-20 \%$ while protein synthesis and energy supply increased by $200-300 \%$. Second, previous comparisons of low- and high-wool-producing sheep using the same procedures showed no relationship between wool production and blood supply or cyst(e)ine flux, but a strong relationship between net cyst(e)ine uptake (and $\left[{ }^{35}\right.$ S]cyst(e)ine uptake) and wool production (Harris et al. 1993) suggesting that transport of cyst(e)ine into the wool follicle cells may be determined genetically and hence be independent of nutrient flux changes.

This work was supported by a grant from the New Zealand Wool Board.

\section{REFERENCES}

Attaix, D., Aurosseau, E., Manghebati, A. \& Arnal, M. (1988). Contribution of liver, skin, and skeletal muscle to whole-body protein synthesis in the young lamb. British Journal of Nutrition 60, 77-84.

Bird, A. R., Chandler, K. D. \& Bell, A. W. (1981). Effects of exercise and plane of nutrition on nutrient utilisation by the hind limb of the sheep. Australian Journal of Biological Science 34, 541-550.

Chapman, R. E. \& Ward, K. A. (1979). Histological and biochemical features of the wool fibre and follicle. In Physiological and Environmental Limitations to Wool Growth, pp. 193-208 [J. L. Black and P. J. Reis, editors]. Armidale, Australia: University of New England Publishing Unit.

Davis, S. R. \& Collier, R. J. (1985). Mammary blood flow and regulation of substrate supply for milk synthesis. Journal of Dairy Science 68, 1041-1058.

Dellow, D. W., Harris, P. M. \& Sinclair, B. R. (1988). Measurement of blood flow in the skin of sheep. Proceedings of the New Zealand Nutrition Society 13, 130-133.

Grubb, B. R. \& Mills, L. P. (1981). Blood oxygen content in microlitre samples using an easy to build galvanic oxygen cell. Journal of Applied Physiology 50, 456-464.

Harris, P. M., Dellow, D. W. \& Sinclair, B. R. (1988). Measurement of blood flow and amino acid metabolism in the skin of sheep. Proceedings of the New Zealand Society of Animal Production 48, 187-189.

Harris, P. M., Dellow, D. W. \& Sinclair, B. R. (1989). Preliminary in vivo measurements of protein and energy metabolism in the skin of sheep. Australian Journal of Agricultural Research 40, 879-888.

Harris, P. M., Lee, J., Gurnsey, M. P., Dellow, D. W. \& Sinclair, B. R. (1993). Measurement of blood flow and metabolite uptake by the skin of fleeceweight-selected and control Romney rams. Australian Journal of Agricultural Research 41, 255-264.

Harris, P. M. \& Lobley, G. E. (1991). Amino acid metabolism in peripheral tissues. In Physiological Aspects of Digestion and Metabolism in Ruminants: Proceedings of the VII International Symposium on Ruminant Physiology, pp. 201-230 [T. Tsuda, Y. Sasaki and R. Kawashima, editors]. San Diego: Academic Press.

Harris, P. M., Lee, J., Sinclair, B. R. \& Treloar, B. P. (1994). The effect of whole body cysteine supplementation on cysteine utilisation by the skin of a well fed sheep. Proceedings of the New Zealand Society of Animal Production 54, (In the Press)

Harris, P. M., Lobley, G. E., Skene, P. A., Buchan, V., Milne, E., Calder, A. G., Garlick, P. J. \& Connell, A. (1992). Effect of food intake on hind-limb and whole-body protein metabolism in young growing sheep : chronic studies based on arterio-venous techniques. British Journal of Nutrition 68, 389-407. 
Lee, J., Harris, P. M., Sinclair, B. R. \& Treloar, B. P. (1993). Whole body metabolism of cysteine and glutathione and their utilization in the skin of Romney sheep: consequences for wool growth. The Journal of Agricultural Science, Cambridge 121, 111-124.

Leng, R. A. \& Stephenson, S. K. (1965). Glucose and acetate metabolism by isolated sheep wool follicles. Archives of Biochemistry and Biophysics 110, 8-15.

Lobley, G. E. (1990). Energy metabolism reactions in ruminant muscle: responses to age, nutrition, and hormonal status. Nutrition and Development 30, 13-34.

Lobley, G. E., Harris, P. M., Skene, P. A., Buchan, V., Milne, E., Calder, A. G., Anderson, S. E., Garlick, P. J. \& Connell, A. (1992). Responses in tissue protein synthesis to sub- and supra-maintenance intake in young growing sheep: comparison of large-dose and continuous-infusion techniques. British Journal of Nutrition $\mathbf{6 8}$, 373-388

MacRae, J. C. \& Lobley, G. E. (1986). Interactions between energy and protein. In Control of Digestion and Metabolism in Ruminants, pp. 367-385 [L. P. Milligan, W. L. Grovum and A. Dobson, editors]. Englewood Cliffs, NJ : Prentice Hall.

Oddy, V. H., Gooden, J. M. \& Annison, E. F. (1984). Partitioning of nutrients in Merino ewes. I. Contribution of skeletal muscle, the pregnant uterus and the lactating mammary gland to total energy expenditure. Australian Journal of Biological Science 37, 357-88.

Oddy, V. H., Gooden, J. M., Hough, G. M., Teleni, E. \& Annison, E. F. (1985). Partitioning of nutrients in Merino ewes. II. Glucose utilization by skeletal muscle, the pregnant uterus and the lactating mammary gland in relation to whole body glucose utilization. Australian Journal of Biological Science 38, 95-108.

Oddy, V. H. \& Lindsay, D. B. (1986). Determination of rates of protein synthesis, gain and degradation in intact hind limb muscle of lambs. Biochemical Journal 233, 417-425.

Statistical Analysis Systems (1985). SAS User's Guide: Statistics, Version 5. Cary, North Carolina: SAS Institute Inc.

Thornberry, K. J. \& Atkins, K. D. (1984). Variation in the non wool components of the greasy fieece over the body of the Merino sheep. Australian Journal of Experimental Agriculture and Animal Husbandry 24, 72-76. 